\title{
In vitro rumen fermentation kinetics, metabolite production, methane and substrate degradability of polyphenol rich plant leaves and their component complete feed blocks
}

\author{
Ganesh N. Aderao ${ }^{2}$, A. Sahoo ${ }^{1 *}$ iD, R. S. Bhatt ${ }^{2}$, P. K. Kumawat ${ }^{2}$ and Lalit Soni ${ }^{2}$
}

\begin{abstract}
Background: This experiment aimed at assessing polyphenol-rich plant biomass to use in complete feed making for the feeding of ruminants.

Methods: An in vitro ruminal evaluation of complete blocks (CFB) with (Acacia nilotica, Ziziphus nummularia leaves) and without (Vigna sinensis hay) polyphenol rich plant leaves was conducted by applying Menke's in vitro gas production (IVGP) technique. A total of six substrates, viz. three forages and three CFBs were subjected to in vitro ruminal fermentation in glass syringes to assess gas and methane production, substrate degradability, and rumen fermentation metabolites.

Results: Total polyphenol content $(\mathrm{g} / \mathrm{Kg}$ ) was 163 in A. nilotica compared to $52.5 \mathrm{in}$ Z. nummularia with a contrasting difference in tannin fractions, higher hydrolysable tannins (HT) in the former (140.1 vs 2.8) and higher condensed (CT) tannins in the later (28.3 vs 7.9). The potential gas production was lower with a higher lag phase (L) in CT containing Z. nummularia and the component feed block. A. nilotica alone and as a constituent of CFB produced higher total gas but with lower methane while the partitioning factor (PF) was higher in $Z$. nummularia and its CFB. Substrate digestibility (both DM and $O M$ ) was lower $(P<0.001)$ in $Z$. nummularia compared to other forages and CFBs. The fermentation metabolites showed a different pattern for forages and their CFBs. The forages showed higher TCA precipitable $N$ and lower acetate: propionate ratio in Z. nummularia while the related trend was found in CFB with $V$. sinensis. Total volatile fatty acid concentration was higher $(P<0.001)$ in $A$. nilotica leaves than $V$. sinensis hay and $Z$. nummularia leaves. It has implication on widening the forage resources and providing opportunity to use forage biomass rich in polyphenolic constituents in judicious proportion for reducing methane and enhancing green livestock production.
\end{abstract}

Conclusion: Above all, higher substrate degradability, propionate production, lower methanogenesis in CFB with A. nilotica leaves may be considered useful. Nevertheless, CFB with Z. nummularia also proved its usefulness with higher TCA precipitable N and PF. It has implication on widening the forage resources and providing opportunity to use polyphenol-rich forage biomass for reducing methane and enhancing green livestock production.

Keywords: Polyphenol, Methane production, Fermentation metabolites, degradability

\footnotetext{
* Correspondence: sahooarta1@gmail.com

${ }^{1}$ Animal Nutrition Division, ICAR- Indian Veterinary Research Institute, 243122,

Izatnagar, UP, India

Full list of author information is available at the end of the article
}

(c) The Author(s). 2018 Open Access This article is distributed under the terms of the Creative Commons Attribution 4.0 International License (http://creativecommons.org/licenses/by/4.0/), which permits unrestricted use, distribution, and reproduction in any medium, provided you give appropriate credit to the original author(s) and the source, provide a link to the Creative Commons license, and indicate if changes were made. The Creative Commons Public Domain Dedication waiver (http://creativecommons.org/publicdomain/zero/1.0/) applies to the data made available in this article, unless otherwise stated. 


\section{Background}

Browses and trees invariably find their place in ruminant ration in most of the tropical countries. Polyphenols are one of the principal components of these feed resources, which have multiple di- and/or tri-hydroxyphenyl units to classify them as 1) condensed tannins, 2) hydrolysable tannins and 3) phlorotannins [1]. These constituents have huge structural diversity and their interactions with intrinsic (plant) and extrinsic (microbes) proteins have a profound effect on the outcome of expected positive effects on ruminal fermentation attributes and implications of their use in preparation of complete feed for ruminants. Exploitation of plant biomass rich in one or the other component polyphenols to manipulate rumen microbial population including methanogens and thereby harnessing positive rumen fermentation metabolites is considered a useful approach. Methane emission from enteric fermentation and manure management are some of the major sources of livestock GHG emission and several studies have been conducted to evaluate effect of various plant secondary metabolites (PSM) for reducing methane production [2-4]. Various phytochemicals like saponins and tannins have been shown to modulate rumen fermentation favourably, and to inhibit methane production in the rumen $[3,4]$.

Leaves with high nutrient content, digestibility and low methane production can be used by marginal and landless farmers as supplementary feed resource for the feeding of small ruminants. Use of browse species containing secondary compounds as feed supplement for ruminants in many parts of the tropics is increasing in order to improve animal performance by diverting energy loss through methane towards production $[5,6]$. The present study was thus aimed at evaluating the effect of polyphenol rich plant leaves alone or as component of complete feed block (CFB) on in vitro rumen fermentation attributes, methane production and substrate degradability.

\section{Methods}

Collection of forages and preparation of complete feed block

Conventional cowpea hay (Vigna sinensis) and polyphenolrich plants Acacia nilotica and Ziziphus nummularia leaves were harvested from the Agricultural Farm area of Central Sheep and Wool Research Institute, Avikanagar and dried in shade. Three different complete feed blocks (CFB) were prepared by incorporating 30 parts of these forages with concentrate mixture (65 parts) and molasses (5 parts). The composition $(\mathrm{kg} / 100 \mathrm{~kg})$ of concentrate mixture was maize 40 , barley 36 , groundnut cake 14, mustard cake 3 , til cake 4 , mineral mixture 2 and common salt 1 . The molasses moiety was first mixed with the concentrate mixture, which followed subsequent mixing with the forages in a mechanical mixer. The composite mixture was then subjected to preparation of CFB by compressing at 5000 psi $\left(351.5 \mathrm{~kg} / \mathrm{cm}^{2}\right)$ using a horizontal CFB making machine developed by NARP, Department of Agricultural Research and Education (DARE), New Delhi.

\section{Sample preparation and analysis}

Representative samples of A. nilotica and Z. nummularia leaves, cowpea ( $V$. sinensis) hay and CFB were collected and dried in hot air oven at $50-55^{\circ} \mathrm{C}(\sim 48 \mathrm{~h})$ till constant weight. The dried samples were ground to pass $1 \mathrm{~mm}$ screen and stored in screw capped polycarbonate vials for further analysis. Chemical composition i.e. DM, $\mathrm{EE}$, ash were analyzed by the methods of AOAC [7]. Nitrogen $(\mathrm{N})$ content of the sample was estimated by distilling the digested sample in distillation unit (Gerhardt Vapodest $45 \mathrm{~s}$, Germany) attached to auto titrator (TitroLine easy). Fiber fractions (i.e. neutral detergent fiber, NDF; acid detergent fiber, ADF) were determined by following the method of Van Soest et al [8]. Acid detergent residue was treated with $72 \% \mathrm{H}_{2} \mathrm{SO}_{4}(w / w)$ and ashed for acid detergent lignin (ADL) estimation. Polyphenol fractions were analyzed by the methods described by Hagerman et al [9]. Folin-Ciocalteu method was used for the determination of total phenols [10]. The condensed tannins (CT) content was analyzed with the help of butanol- $\mathrm{HCl}$ reagent in the presence of ferric ammonium sulphate, and CT ( $/ \mathrm{Kg} \mathrm{DM})$ is expressed as leucocyanidin equivalent.

$$
\begin{aligned}
\mathrm{CT}(\mathrm{g} / \mathrm{Kg})= & \left(\mathrm{A}_{550} \mathrm{~nm} \times 78.26 \times \text { Dilution factor }\right) / \\
& (\% \text { Dry matter }) \times 10 \mathrm{a}
\end{aligned}
$$

Where, $\mathrm{A}_{550} \mathrm{~nm}$ is absorbance at $550 \mathrm{~nm}$.

For non-tannin phenolics (NTP) estimation, accurately weighed $100 \mathrm{mg}$ PVPP, $1 \mathrm{~mL}$ each of distilled water and tannin-containing extract was transferred to a $15 \mathrm{~mL}$ test tube. Thereafter, the tubes were vortexed and kept at $4{ }^{\circ} \mathrm{C}$ for $15 \mathrm{~min}$. and then centrifuged at $3000 \mathrm{rpm}$ for $10 \mathrm{~min}$ to collect the supernatant, which was estimated for NTP by Folin-Ciocalteu method [10] and expressed as $\mathrm{g} / \mathrm{Kg}$ DM. Total tannin phenols (TTP) were calculated as the difference between TP and NTP. Hydrolysable tannin (HT) was calculated as the difference between TTP and CT.

\section{In vitro gas production (IVGP) test}

In vitro gas production (IVGP) technique of Menke et al [11] was followed for ruminal fermentation in glass syringes. Rumen liquor was collected from adult male rams being fed near maintenance in the morning (before feeding) with the help of stomach tube attached to a suction pump. It was transferred to a pre-warmed $\mathrm{CO}_{2}$ 
filled thermos, and immediately carried to the laboratory (max - $30 \mathrm{~min}$ ). Rumen fluid from different rams collected was mixed in equal proportion, and filtered through four layered muslin cloth under continuous flushing of $\mathrm{CO}_{2}$ to maintain anaerobiosis. Oven-dried samples (200 $\mathrm{mg}$ ) in triplicate were weighed into $100 \mathrm{~mL}$ calibrated glass syringes fitted with plungers. Syringes were filled with $30 \mathrm{~mL}$ of medium consisting of $10 \mathrm{~mL}$ rumen fluid and $20 \mathrm{~mL}$ buffer solution. Three blank syringes were also incubated with only $30 \mathrm{~mL}$ of the medium. The syringes were placed in hot water bath cum shaker maintained at $39{ }^{\circ} \mathrm{C}$. Gas production (GP) was recorded after 2, 4, 6, 8, $1012,18,24,30,36,4872$ and $96 \mathrm{~h}$ of incubation. Net GP by each sample during the above mentioned period was calculated by subtracting the gas produced of the blank. The data so generated was processed as per Sigmastat Software (version 3.5) for calculating time to reach half asymptote $\left(\mathrm{t}^{1 / 2} ; \mathrm{h}\right)$, potential GP (mg/200 mg substrate), rate constant (c) and lag phase $(\mathrm{L} ; \mathrm{h})$. The GP kinetic parameters were calculated from the time dependent ( 0 to $96 \mathrm{~h}$ ) in vitro cumulative GP data by applying single pool logistic model as depicted below. The assumptions were made that the rate of GP is proportional to both the accumulated microbial mass and to the amount of digestible substrate remaining [12].

$$
\mathrm{Y}(\mathrm{t})=\mathrm{b} /[(1+\exp \{(2+4 \mathrm{c}(\mathrm{L}-\mathrm{t})\}]
$$

Where, $\mathrm{Y}(\mathrm{t})=\mathrm{GP}(\mathrm{mL})$ after time $\mathrm{t}, \mathrm{b}=$ asymptotic value of the component (total potential GP, $\mathrm{mL}$ ), $\mathrm{c}=$ specific rate of fermentation and $\mathrm{L}=$ lag time (the time axis intercept).

\section{Gas production and methane assay}

After calculation of fermentation constants, two sets of samples each in triplicate were run simultaneously. In set one $200 \mathrm{mg}$ and in set two $400 \mathrm{mg}$ of oven dried samples weighed in to $100-\mathrm{mL}$ glass syringes fitted with waxed plungers and were incubated with rumen buffer medium. In set one $30 \mathrm{~mL}$ and in set two $40 \mathrm{~mL}$ of the medium (with double strength buffer) was added as per the modified method of Menke and Steingass [13]. Samples were incubated in hot water bath cum shaker maintained at $39{ }^{\circ} \mathrm{C}$ up to $24 \mathrm{~h}$ and total GP was recorded. The gas sample from the first set was analyzed for methane concentration and fermentation was terminated by keeping the syringes in ice water. Methane $\left(\mathrm{CH}_{4}\right)$ was analyzed by Gas Chromatograph (Model 1000, Series 011124002 of DANI make, Italy) using FID with PTV column. The temperature of injection port was $120{ }^{\circ} \mathrm{C}$; column $50{ }^{\circ} \mathrm{C}$; detector $120{ }^{\circ} \mathrm{C}$. The flow rate of carrier gas (nitrogen) was $30 \mathrm{~mL} / \mathrm{min}$; hydrogen $30 \mathrm{~mL} / \mathrm{min}$; air $300 \mathrm{~mL} / \mathrm{min}$. The standard gas used for methane estimation composed of 99.998\% methane (Sigma-Aldrich; Missouri, United States). Methane concentration was calculated by comparing the peak area of standard with samples. Methane production was calculated by applying the following equation.

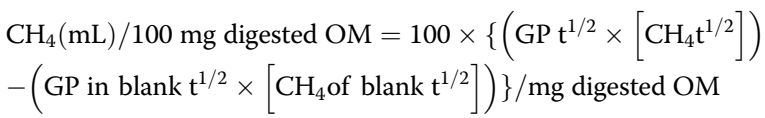

\section{Substrate degradability}

The sample in set two (400 mg sample) syringes after incubation for $24 \mathrm{~h}$ was transferred to $600 \mathrm{~mL}$ spoutless beaker and $100 \mathrm{~mL}$ of neutral detergent solution was added after washing the in vitro syringes with the same solution (for ensuring quantitative transfer) and refluxed for $1 \mathrm{~h}$ as practiced during NDF assay. The samples were then filtered and washed through pre-weighed sintered glass crucibles (G-1) and the residue was dried in hot air oven at $100{ }^{\circ} \mathrm{C}$ for $24 \mathrm{~h}$ and weighed. The crucible with residue was incinerated in muffle furnace at $600{ }^{\circ} \mathrm{C}$ for $4 \mathrm{~h}$ and weighed next day after cooling. OM digestibility was calculated after necessary corrections for the blank samples.

\section{Statistical analysis}

Analysis of variance was employed for data analysis following General Linear Model (GLM) procedure using statistical software SPSS (version 16). Tukey's test was utilized to compare significant differences $(P<0.05)$ among the means for the two set of substrates (roughages and CFBs).

\section{Results}

\section{Nutrient and polyphenolic composition}

The nutrient composition of $V$. sinensis hay, A. nilotica leaves, $Z$. nummularia leaves revealed similar CP contents (140-145 g/Kg) with a varied fiber fractions, viz. comparatively high NDF, ADF and lignin in polyphenol-rich forages than $V$. sinensis hay (Table 1 ). The CFB's containing aforementioned roughages followed a similar pattern for these nutrients. The polyphenolic fractions of these forages revealed low total phenol (TP) in V. sinensis ( $3.9 \mathrm{~g} /$ $\mathrm{Kg})$ compared to A. nilotica $(163 \mathrm{~g} / \mathrm{Kg})$ and $Z$. nummularia $(52.5 \mathrm{~g} / \mathrm{Kg})$. A. nilotica had high TTP and HT whereas NTP and CT contents were higher in Z. nummularia (21.4 and $28.3 \mathrm{~g} / \mathrm{Kg}$ ). The polyphenolic composition of CFB followed a similar trend as it was for the component roughage moiety.

\section{In vitro gas and methane production}

In vitro fermentation constants, gas, methane production and substrate degradability of roughages revealed (Table 2) highest gas production (GP) in A. nilotica 
Table 1 Chemical and polyphenol constituents ( $\mathrm{g} / \mathrm{kg}$ dry matter) of roughage components and complete feed block (CFB)

\begin{tabular}{|c|c|c|c|c|c|c|}
\hline Constituents & Vigna sinensis hay & Acacia nilotica leaves & Ziziphus nummularia leaves & CFB 1 & CFB 2 & CFB 3 \\
\hline$\overline{\mathrm{DM}}$ & 892 & 902 & 865 & 888 & 902 & 899 \\
\hline $\mathrm{OM}$ & 882 & 876 & 874 & 909 & 896 & 902 \\
\hline Ash & 118 & 124 & 126 & 91 & 104 & 97.8 \\
\hline $\mathrm{CP}$ & 144 & 145 & 140 & 153 & 155 & 150 \\
\hline EE & 25.4 & 25.7 & 32.1 & 52.1 & 53 & 54.8 \\
\hline NDF & 608 & 695 & 657 & 374 & 400 & 389 \\
\hline ADF & 451 & 468 & 473 & 252 & 257 & 259 \\
\hline$A D L$ & 108 & 124 & 196 & 60.4 & 65 & 86.6 \\
\hline Hemicellulose & 157 & 227 & 184 & 122 & 143 & 130 \\
\hline Cellulose & 343 & 344 & 277 & 192 & 192 & 172 \\
\hline Total phenols & 3.9 & 163 & 52.5 & 2.7 & 45.2 & 16.3 \\
\hline Total tannin phenols & 2.9 & 148 & 31.1 & 2.1 & 40.4 & 9.4 \\
\hline Non-tannin phenols & 1 & 15 & 21.4 & 0.6 & 4.8 & 6.9 \\
\hline Condensed tannins & 1.2 & 7.9 & 28.3 & 1.8 & 2.3 & 8.2 \\
\hline Hydrolysable tannins & 1.7 & 140.1 & 2.8 & 0.3 & 38.1 & 1.2 \\
\hline
\end{tabular}

CFB1 Concentrate mixture + Vigna sinensis hay (70:30), CFB2 Concentrate mixture + Acacia nilotica leaves (70:30), CFB3 concentrate mixture + Ziziphus nummularia leaves (70:30)

leaves (151 $\mathrm{mL} / \mathrm{g} \mathrm{DM})$ followed by $V$. sinensis hay (137 $\mathrm{mL} / \mathrm{g} \mathrm{DM})$ and Z. nummularia leaves $(126 \mathrm{~mL} / \mathrm{g}$ $\mathrm{DM})$. Potential gas production (mL/200 mg DM) was significantly higher $(P<0.05)$ for $V$. sinensis hay $(42.1)$ and $A$. nilotica (40.9) as compared to $Z$. nummularia leaves (37.9). The $t^{1} \frac{1}{2}$ was significantly lower $(P<0.05)$ in $A$. nilotica leaves as compared to $V$. sinensis hay and $Z$. nummularia leaves. Total methane produced per $g$ of substrate was $28.4,12.7$ and $23.0 \mathrm{~mL}$ in these feed resources. DMD and OMD were higher in A. nilotica leaves $(65.0,68.8 \%)$ followed by $V$. sinensis hay $(57.7$ and $64.6 \%)$ and lowest value was observed in $Z$. nummularia leaves $(54.9$ and $60.2 \%)$. Significant $(P<0.05)$ difference were observed in methane production per $g$ digestible $\mathrm{DM} / \mathrm{OM}$ in different feed resources, viz. $V$. sinensis hay produced highest methane per unit of digestible DM and OM $(49.1,49.8 \mathrm{~mL})$ followed by $Z$. nummularia leaves $(41.9,43.8 \mathrm{~mL})$ and lowest in $A$. nilotica leaves (19.6, $22.3 \mathrm{~mL})$. Amongst the CFBs, highest $(P<0.05)$ GP was recorded in CFB2 $(233 \mathrm{~mL} / \mathrm{g} \mathrm{DM})$ followed by

Table 2 In vitro fermentation constants, degradability and methane production of different forages

\begin{tabular}{|c|c|c|c|c|c|}
\hline Attributes & Vigna sinensis Hay & Acacia nilotica leaves & Ziziphus nummularia leaves & SEM & Significance ( $P$ value) \\
\hline \multicolumn{6}{|l|}{ Fermentation kinetics } \\
\hline Potential gas production (ml/200 mg DM) & 42.1 & 40.9 & 37.9 & 0.926 & 0.021 \\
\hline Rate constant (c) & 0.044 & 0.061 & 0.049 & 0.005 & 0.001 \\
\hline Half time $\left(t^{1 / 2}, h\right)$ & 15.6 & 11.4 & 14.0 & 0.71 & 0.018 \\
\hline Lag phase (L, h) & 1.90 & 3.33 & 5.37 & 1.16 & 0.012 \\
\hline \multicolumn{6}{|l|}{ Degradability and methane production } \\
\hline DMD \% & $57.7^{b}$ & $65.0^{a}$ & $54.9^{c}$ & 0.31 & $<0.001$ \\
\hline OMD \% & $64.6^{b}$ & $68.8^{a}$ & $60.2^{c}$ & 0.59 & $<0.001$ \\
\hline Gas production (mL/g) & $137^{b}$ & $151^{a}$ & $126^{c}$ & 3.1 & $<0.001$ \\
\hline Gas production (mL/g DDM) & $237^{\mathrm{a}}$ & $232^{\mathrm{ab}}$ & $229^{b}$ & 2.5 & 0.024 \\
\hline Gas production (mL/g DOM) & 240 & 250 & 239 & 5.2 & 0.541 \\
\hline Methane production (mL/g DM) & $28.4^{a}$ & $12.7^{c}$ & $23.0^{b}$ & 0.95 & $<0.001$ \\
\hline Methane production (mL/g DDM) & $49.1^{a}$ & $19.6^{c}$ & $41.9^{b}$ & 1.36 & $<0.001$ \\
\hline Methane production (mL/g OMD) & $49.8^{a}$ & $22.3^{c}$ & $43.8^{b}$ & 0.70 & $<0.001$ \\
\hline Partitioning factor $(\mathrm{g} / \mathrm{mL})$ & $4.16^{b}$ & $3.99^{\mathrm{a}}$ & $4.18^{b}$ & 0.038 & 0.042 \\
\hline
\end{tabular}

Means bearing different superscript $\left({ }^{a, b}, c\right)$ differ significantly

$\mu \mathrm{m}=$ maximum rate of $\mathrm{GP}(\mathrm{b} \times \mathrm{c})$ At the inflection point $(\mathrm{Y}=\mathrm{b} / 2)$, i.e. inflection occurs halfway to the maximum gas volume and thus, $\mathrm{t}_{1 / 2}=\mathrm{L}+(\mu \mathrm{m} \times \mathrm{b} / 2)$ 
CFB1 $(221 \mathrm{~mL} / \mathrm{g}$ DM) and CFB3 $(184 \mathrm{~mL} / \mathrm{g} \mathrm{DM})$ (Table 3). Potential gas production (mL/200 mg DM) was significantly lower $(P<0.05)$ in CFB3 as compared to CFB1 and CFB2. There was no significant difference observed for $t^{1} 12$, rate constant and lag phase among CFBs. Methane produced per $\mathrm{g}$ of substrate was 50.8, 29.8 and $34.0 \mathrm{~mL}$ in CFBs.

\section{Substrate degradability and partitioning factor}

Degradability of DM and OM was higher in CFB2 (82.0 and $86.6 \%$ ) followed by CFB1 (79.5 and $81.8 \%$ ) and lowest in CFB3 (75.6 and 80.3\%) (Table 3). Similarly, significant $(\mathrm{P}<0.05)$ difference were observed in methane production per unit digestible substrates, wherein CFB1 produced highest methane per unit of degradable DM and OM (63.9 and $68.3 \mathrm{~mL}$ ) followed by CFB3 (47.5 and $47.0 \mathrm{~mL})$ and lowest value $(34.3$ and $38.3 \mathrm{~mL}$ ) was recorded in CFB2. The trend was in line with the roughage components (Table 2). The partitioning factor (PF) was low in A. nilotica leaves compared to other two roughages. However, the feed blocks containing these roughages showed a different pattern, being higher in CFB3 compared to CFB1 and CFB2.

\section{Rumen fermentation metabolites}

A. nilotica leaves showed higher $(P<0.05)$ total $\mathrm{N}$ and $\mathrm{NH}_{3}-\mathrm{N}$ values than the other two substrates (Table 4). TCA precipitable $\mathrm{N}$ content was higher $(P<0.001)$ in $Z$. nummularia leaves than $A$. nilotica leaves, which was higher than $V$. sinensis hay. The VFA profile showed higher $(P<0.05)$ TVFA including acetate, propionate and other VFA fractions in A. nilotica leaves as compared to $Z$. nummularia and $V$. sinensis hay. The ratio of nonglucogenic to glucogenic VFA and acetate and propionate ratio were higher $(P<0.05)$ in $A$. nilotica leaves than the $Z$. nummularia leaves and $V$. sinensis hay.

The $\mathrm{pH}$ was similar and total $\mathrm{N}(\mathrm{mg} / \mathrm{dL})$ values ranged from 91.3 (CFB2) to 115.1 (CFB3) showing significant difference between the CFBs (Table 5). Conversely, the ammonia $\mathrm{N}$ concentration was higher $(P<0.05)$ in CFB2 than CFB1 and CFB3. The TCA precipitable $\mathrm{N}$ ranged from 44.6 in CFB2 to 78.8 in CFB1. Total VFA (mM/L) production was highest from CFB2 (48.7) followed by CFB1 (42.7) and CFB3 (25.4) and the concentration of acetate, propionate, BcFA and other FA followed a similar trend. The acetate: propionate ratio was higher $(\mathrm{P}<0.05)$ in CFB3, but the ratio of nonglucogenic to glucogenic VFA was non-significantly different between the $\mathrm{CFB}$ types. The proportion of propionate was higher $(\mathrm{P}<0.05)$ in $\mathrm{CFB} 1$ and $\mathrm{CFB} 2$ than CFB3.

\section{Discussion}

The nutrient composition of the three roughage moieties in the CFB, $V$. sinensis hay, A. nilotica leaves and $Z$. nummularia leaves are in line with the documented information [14, 15]. Total polyphenolic constituents in $A$. nilotica was higher than $Z$. nummularia leaves, but the tannin polyphenolic fractions $(\mathrm{g} / \mathrm{Kg} \mathrm{DM})$ revealed a different pattern, the former was rich in HT (140) while the later was rich in CT (28.3). Similar polyphenolic composition in these tree leaves has also been reported earlier $[16,17]$ and in $\mathrm{CFB}$, the level of polyphenolic

Table 3 In vitro fermentation constants, degradability and methane production of complete feed block (CFB)

\begin{tabular}{|c|c|c|c|c|c|}
\hline Attributes & CFB1 & CFB2 & CFB3 & SEM & Significance ( $P$ value) \\
\hline \multicolumn{6}{|l|}{ Fermentation kinetics } \\
\hline Potential Gas Production (ml/200 mg DM) & 61.9 & 61.4 & 55.4 & 1.096 & 0.031 \\
\hline Rate Constant (c) & 0.059 & 0.064 & 0.060 & 0.005 & 0.082 \\
\hline Half time $\left(t^{1 / 2} h\right)$ & 11.7 & 10.8 & 11.6 & 1.12 & 1.121 \\
\hline Lag phase (h) & 1.69 & 3.23 & 3.75 & 1.607 & 0.094 \\
\hline \multicolumn{6}{|l|}{ Degradability and methane production } \\
\hline DMD \% & $79.5^{\mathrm{a}}$ & $82.0^{\mathrm{a}}$ & $74.0^{c}$ & 0.609 & $<0.001$ \\
\hline OMD \% & $81.8^{\mathrm{b}}$ & $86.6^{\mathrm{a}}$ & $80.3^{c}$ & 0.379 & $<0.001$ \\
\hline Gas production (mL/g) & $221^{\mathrm{a}}$ & $233^{\mathrm{a}}$ & $184^{\mathrm{b}}$ & 5.34 & $<0.001$ \\
\hline Gas production (mL/g DDM) & 278 & 284 & 246 & 6.43 & 0.152 \\
\hline Gas production (mL/g DOM) & $297^{a}$ & $300^{\mathrm{a}}$ & $254^{\mathrm{b}}$ & 6.45 & 0.012 \\
\hline Methane production (mL/g DM) & $50.8^{\mathrm{a}}$ & $29.8^{c}$ & $34.0^{b}$ & 1.64 & $<0.001$ \\
\hline Methane production (mL/g DDM) & $63.9^{\mathrm{a}}$ & $36.3^{c}$ & $45.9^{b}$ & 2.11 & $<0.001$ \\
\hline Methane production (mL/g DOM) & $68.3^{\mathrm{a}}$ & $38.3^{c}$ & $47.0^{\mathrm{b}}$ & 0.809 & $<0.001$ \\
\hline Partitioning factor ( $\mathrm{g} / \mathrm{mL})$ & $3.36^{\mathrm{a}}$ & $3.33^{\mathrm{a}}$ & $3.94^{\mathrm{b}}$ & 0.016 & $<0.001$ \\
\hline
\end{tabular}

Means bearing different superscript $\left({ }^{a}, b, c\right)$ differ significantly

CFB1 Concentrate mixture + Vigna sinensis hay (70:30), CFB2 Concentrate mixture + Acacia nilotica leaves (70:30), CFB3 Concentrate mixture + Ziziphus nummularia leaves (70:30) 
Table 4 In vitro ruminal fermentation metabolites of different forages

\begin{tabular}{|c|c|c|c|c|c|}
\hline \multirow[t]{2}{*}{ Attributes } & \multicolumn{3}{|l|}{ Roughage } & \multirow[t]{2}{*}{ SEM } & \multirow{2}{*}{$\begin{array}{l}\text { Significance } \\
\text { ( } P \text { value) }\end{array}$} \\
\hline & Vigna sinensis hay & Acacia nilotica leaves & Ziziphus nummularia leaves & & \\
\hline Total N (mg/dL) & $47.3^{c}$ & $57.1^{\mathrm{b}}$ & $60.5^{a}$ & 0.459 & $<0.001$ \\
\hline Ammonia N (mg/dL) & $16.4^{\mathrm{b}}$ & $17.3^{\mathrm{a}}$ & $16.4^{\mathrm{b}}$ & 0.209 & 0.046 \\
\hline TCA precipitable N (mg/dL) & $15.7^{\mathrm{b}}$ & $10.8^{c}$ & $21.8^{\mathrm{a}}$ & 0.971 & $<0.001$ \\
\hline Acetic acid (mM/L) & $26.3^{b}$ & $31.3^{\mathrm{a}}$ & $11.1^{c}$ & 0.759 & $<0.001$ \\
\hline Propionic acid (mM/L) & $5.31^{\mathrm{a}}$ & $5.06^{\mathrm{a}}$ & $2.60^{b}$ & 0.159 & $<0.001$ \\
\hline Isobutyric acid (mM/L) & $0.88^{\mathrm{a}}$ & $0.89^{a}$ & $0.26^{b}$ & 0.021 & $<0.001$ \\
\hline Butyric acid (mM/L) & $2.89^{\mathrm{a}}$ & $2.68^{\mathrm{a}}$ & $2.28^{\mathrm{b}}$ & 0.069 & 0.003 \\
\hline Isovaleric acid (mM/L) & $0.75^{\mathrm{a}}$ & $0.89^{\mathrm{a}}$ & $0.24^{b}$ & 0.039 & $<0.001$ \\
\hline Valeric acid (mM/L) & 0.37 & 0.34 & 0.64 & 0.103 & 0.137 \\
\hline Total VFA (mM/L) & $36.5^{b}$ & $41.2^{\mathrm{a}}$ & $17.1^{c}$ & 0.911 & $<0.001$ \\
\hline Branch-chain fatty acids (mM/L) & $2.00^{\mathrm{a}}$ & $2.13^{\mathrm{a}}$ & $1.15^{\mathrm{b}}$ & 0.119 & 0.002 \\
\hline Acetate: propionate ratio & $4.96^{\mathrm{b}}$ & $6.18^{\mathrm{a}}$ & $4.25^{c}$ & 0.11 & $<0.001$ \\
\hline Non-glucogenic: glucogenic VFA ratio & $4.66^{\mathrm{b}}$ & $5.40^{\mathrm{a}}$ & $4.47^{\mathrm{b}}$ & 0.11 & 0.002 \\
\hline
\end{tabular}

Means bearing different superscript $\left({ }^{a, b}, c\right)$ differ significantly

TCA Trichloroaceticic acid, VFA Volatile fatty acids

constituents followed the trend as that in respective roughage source.

The three roughage substrates were degraded differently in the in vitro ruminal fermentation system. The substrate from $A$. nilotica leaves was degraded at the highest rate and it was not affected by the increased level of HT. On the contrary, Z. nummularia leaves showed a lower degradability value compared to conventional $V$. sinensis hay, due probably to the presence of higher CT and lignin content [3]. These values were comparable in $A$. nilotica leaves and $V$. sinensis hay. A similar trend in OM degradability between the substrates could also be attributed to this variation in chemical constituents. Alteration in substrate degradability due to differences in chemical composition is quite obvious $[3,16]$. Consequently, $t^{1 / 2}$ was lowest in A. nilotica leaves followed by $Z$. nummularia leaves and highest in $V$. sinensis hay. This was in direct relation with the degradability, as stated earlier by Sahoo et al [18] that halfway time to maximum gas volume is positively correlated with speed of microbial attachment and

Table 5 In vitro ruminal fermentation metabolites of complete feed block (CFB)

\begin{tabular}{|c|c|c|c|c|c|}
\hline \multirow[t]{2}{*}{ Attributes } & \multicolumn{5}{|c|}{ Complete feed block } \\
\hline & CFB1 & CFB2 & CFB3 & SEM & Significance ( $P$ value) \\
\hline Total N (mg/dL) & $103^{b}$ & $91.3^{c}$ & $115^{a}$ & 1.52 & $<0.001$ \\
\hline Ammonia N (mg/dL) & $18.1^{\mathrm{b}}$ & $20.8^{a}$ & $17.8^{\mathrm{b}}$ & 0.209 & $<0.001$ \\
\hline TCA precipitable $\mathrm{N}(\mathrm{mg} / \mathrm{dL})$ & $78.8^{\mathrm{a}}$ & $44.6^{c}$ & $70.3^{b}$ & 1.67 & $<0.001$ \\
\hline Acetic acid (mM/L) & $29.8^{\mathrm{a}}$ & $33.6^{\mathrm{a}}$ & $17.9^{\mathrm{b}}$ & 1.73 & $<0.001$ \\
\hline Propionic acid (mM/L) & $6.53^{\mathrm{a}}$ & $7.44^{\mathrm{a}}$ & $3.47^{b}$ & 0.351 & $<0.001$ \\
\hline Isobutyric acid (mM/L) & $0.95^{\mathrm{a}}$ & $1.00^{\mathrm{a}}$ & $0.37^{\mathrm{b}}$ & 0.029 & $<0.001$ \\
\hline Butyric acid (mM/L) & $4.19^{b}$ & $5.03^{\mathrm{a}}$ & $2.50^{c}$ & 0.179 & $<0.001$ \\
\hline Isovaleric acid (mM/L) & $0.89^{\mathrm{b}}$ & $1.09^{\mathrm{a}}$ & $0.29^{c}$ & 0.029 & $<0.001$ \\
\hline Valeric acid (mM/L) & $0.41^{b}$ & $0.45^{\mathrm{b}}$ & $0.95^{\mathrm{a}}$ & 0.041 & $<0.001$ \\
\hline Total VFA (mM/L) & $42.8^{\mathrm{a}}$ & $48.6^{\mathrm{a}}$ & $25.5^{\mathrm{b}}$ & 2.2 & $<0.001$ \\
\hline Branch-chain fatty acids (mM/L) & $2.24^{b}$ & $2.54^{\mathrm{a}}$ & $1.61^{c}$ & 0.063 & $<0.001$ \\
\hline Acetate: propionate ratio & $4.54^{\mathrm{b}}$ & $4.54^{\mathrm{b}}$ & $5.13^{\mathrm{a}}$ & 0.148 & 0.047 \\
\hline Nonglucogenic: glucogenic VFA ratio & 4.59 & 4.64 & 4.82 & 0.108 & 0.38 \\
\hline
\end{tabular}

Means bearing different superscript $\left({ }^{\mathrm{a}, \mathrm{b}, \mathrm{c}}\right)$ differ significantly

TCA Trichloroaceticic acid, VFA Volatile fatty acids

CFB1 Concentrate mixture + Vigna sinensis hay (70:30), CFB2 Concentrate mixture + Acacia nilotica leaves (70:30), CFB3 Concentrate mixture + Ziziphus nummularia leaves (70:30) 
rate of degradation, which ultimately decides substrate degradability of forages. The rate constant was higher for $A$. nilotica and $Z$. nummularia leaves and lowest in $V$. sinensis hay. Different feedstuffs always demonstrate difference in rate constants during kinetic assay [19]. A high rate constant for A. nilotica leaves is justifiable from their higher GP. However, higher rate constant for $V$. sinensis hay may be ascribed to lowest NDF and high lignin.

A direct correlation does exist between substrate degradability, short-chain fatty acid production and IVGP [20]. Accordingly, A. nilotica leaves and CFB2 revealed higher GP. Expression of GP per unit digestible DM and $\mathrm{OM}$ registered higher values but the differences between the substrates narrowed down where all the three substrates had similar values because of variability in digestibility. This could be attributed to intrinsic higher CT [21] and lignin [3] content in Z. nummularia leaves compared to $V$. sinensis hay and $A$. nilotica leaves. These $\mathrm{CT}$ is having negative effect on GP because of their ability to interact with protein and fiber fractions, thereby reducing microbial enzymatic degradation (precipitate microbial enzymes) and microbial growth [3, 22, 23]. Highest DM and OM degradability in CFB2 followed by CFB1 and lowest in CFB3 was in line with CFBs with respective constituent roughages. Higher degradability was evidenced by higher GP in CFBs. Similar results were also observed by Bhatta et al. [23]. On similar line, low methane production by $A$. nilotica leaves may be attributed to its higher TTP compared to other forages. In tropical legumes, content of tannins and other secondary metabolites is higher that affects NDF digestibility and reduce methane production [24]. Methane inhibition activity observed in $Z$. nummularia leaves could thus be attributed to presence of CT. This alternatively produced positive fermentation pattern with better acetate: propionate and nonglucogenic: glucogenic VFA ratio [25]. Plants rich in tannins [25] and saponins [26] have potential for enhancing flow of microbial protein from rumen, increasing efficiency of feed utilization and decreasing methanogenesis. The CFB containing these plant biomass recorded a similar pattern and it was observed earlier too [3]. A lower methane emission for some shrubs (e.g. Z. nummularia) than other forages could thus be attributed to presence of various phytochemicals $[3,23,27]$. It has been suggested that the action of tannins on methanogenesis is attributed to direct inhibitory effects on methanogens [28] depending upon the chemical structure of tannins, and also indirectly by decreasing fiber degradation $[3,26,29]$.

The data on fermentation metabolites was inconsistent in both roughage components and the CFBs. Variation in total $\mathrm{N}$ concentration in the digesta as against relatively similar $\mathrm{N}$ content in the three roughages was indicative of different fermentation behaviour effected by dissimilar phytochemicals. The concentration of ammonia $\mathrm{N}$ and TCA-precipitable $\mathrm{N}$ did not show any definite correlation. A higher ammonia $\mathrm{N}$ in A. nilotica leaves with intermediate total $\mathrm{N}$ concentration led to lower TCA-precipitable $\mathrm{N}$ compared to $V$. sinensis hay and $Z$. nummularia leaves. This reduction in TCA-precipitable $\mathrm{N}$ may be due to the harmful effects of higher HT and total polyphenol content on ruminal microbes responsible for metabolism of $\mathrm{N}$ fractions. Moreover, negative correlation between polyphenol content and TCA-precipitable $\mathrm{N}$ has also been reported [3]. Total VFA concentration was in line with substrate fermentation that degraded at higher rate to produce more gas. Similar correlation was observed earlier $[3,18,20]$ and it is emphasized that the amount of gas produced from feeds depends largely upon chemical composition and rate and extent of degradability of feeds and production of VFA and their proportion. The proportion of acetate and other branched chain fatty acids (BcFA) that revealed better acetate: propionate ratio and nonglucogenic: glucogenic VFA ratio could be attributed to interaction of CT and other non-polyphenolic polymer lignin. Evidently, it was associated with higher proportion of propionate, butyrate and other BcFA in $Z$. nummularia leaves. A different trend in CFB with $Z$. nummularia leaves commensurate with higher $\mathrm{CT}$ and lignin content.

Preparation of total mixed ration based compact feed block involving crop residues, tree leaves and browses presents altogether a different substrate for ruminal microbial degradation that have different proportional distribution of soluble and insoluble carbohydrates, proteins and fats. Moreover, ruminal fermentation is a dynamic process involving production of fermentation metabolites, microbial synthesis and multiplication associated with gradual decline in substrate availability consequent upon its degradability and ensuing alteration in the total fermentation process. Consequently, the PF that demonstrates partitioning of nutrients in to microbial protein synthesis [20] may become a critical determinant to establish correlation between true substrate degradability and production of shortchain fatty acids, fermentable gas and methane production.

\section{Conclusion}

The complete feed with HTrich A. nilotica leaves exhibited higher substrate degradability, propionate production and lower methanogenesis. On the other hand, CFB with CTrich $Z$. nummularia leaves produced lower fermentable gas, VFA with higher PF to emphasize its usefulness. This conflict could only be addressed by in vivo experiments. Nevertheless, this in vitro ruminal assessment of polyphenol-rich plant biomass and the CFBs could certainly elaborate the diverse effects on ruminal fermentation behaviour between polyphenolic constituents HT and CT. 
Therefore, judicious incorporation of $A$. nilotica and $Z$. nummularia leaves in complete feeds would promise better ruminant production. Besides, inclusion of these leaves as part of total mixed ration would eventually help in delivering positive fermentation attributes by minimizing their antinutritional effects. Finally, polyphenol rich plant leaves can be used for strategic reduction of methane emission from the animals thereby diverting the energy for higher production with better feed efficiency.

\section{Abbreviations}

ADF: Acid detergent fiber; ADL: Acid detergent lignin; BCFA: Branched-chain fatty acids; BW: Body weight; CFB: Complete feed block; CP: Crude protein; CRD: Complete randomized experimental design; $C$ : Condensed tannins; DM: Dry matter; DM: Dry matter; DWG: Daily weight gain; EE: Ether extract; FA: Fatty acids; FID: Flame-ionization detector; GP: Gas production; HCl: Hydrochloric acid; HT: Hydrolysable tannins; IVGP: In vitro gas production; ME: Metabolizable energy; N: Nitrogen; NDF: Neutral detergent fiber; NTP: Non-tannin phenols; OM: Organic matter; PTV: Programmable temperature vaporizer; TCA: Trichloro acetic acid; TP: Total phenols; TTP: Total tannin phenols; VFA: volatile fatty acids

\section{Acknowledgements}

Authors are thankful to ICAR-Central Sheep and Wool Research Institute, Avikanagar and ICAR- Indian Veterinary Research Institute, Izatnagar for providing necessary facilities to carry out this work.

\section{Funding}

No external source of fund is received for this experimentation.

\section{Availability of data and materials}

Authors approved availability of data and materials.

\section{Authors' contributions}

GNA implemented the experimental protocol and drafted the manuscript; AS designed the experiment, monitored implementation and interpreted the result; RSB helped in implementation and data analysis; PKK helped in chemical analysis and LS helped in chemical analysis. All authors read and approved the final manuscript.

\section{Ethics approval}

All experimental procedures involving animals were duly approved by Institute (CSWRI, Avikanagar) Animal Ethics Committee (IAEC) (approval number IAEC-CSWRI/2017/IXX13455) by following the guidelines of Committee for the Purpose of Control and Supervision of Experiments on Animals (CPCSEA).

\section{Consent for publication}

Not applicable.

\section{Competing interests}

The authors declare that they have no competing interests.

\section{Publisher's Note}

Springer Nature remains neutral with regard to jurisdictional claims in published maps and institutional affiliations.

\footnotetext{
Author details

'Animal Nutrition Division, ICAR- Indian Veterinary Research Institute, 243122, Izatnagar, UP, India. 'Division of Animal Nutrition Division, ICAR- Central Sheep and Wool Research Institute, Avikanagar, Rajasthan 304501, India.

Received: 4 July 2018 Accepted: 29 October 2018

Published online: 09 November 2018

\section{References}

1. Haslam E. Practical polyphenolics: from structure to molecular recognition and physiological action. New York: Cambridge University Press; 1998.
}

2. Kamra DN, Agarwal N, Chaudhary LC. Inhibition of ruminal methanogenesis by tropical plants containing secondary compounds. Int Cong Ser. 2006; 1293:156-63.

3. Pal K, Patra AK, Sahoo A. Evaluation of feeds from tropical origin for in vitro methane production potential and rumen fermentation in vitro. Span J Agric Res. 2015;13:e0608.

4. Jadhav RV, Kannan A, Bhar R, Sharma OP, Gulati A, Rajkumar K, Verma MR. Effect of tea (Camellia sinensis) seed saponins on in vitro rumen fermentation, methane production and true digestibility at different forage to concentrate ratios. J Appl Anim Res. 2018:46:118-24.

5. Abdulrazak SA, Fujihara T, Ondiek JK, Ørskov ER. Nutritive evaluation of some Acacia tree leaves from Kenya. Anim Feed Sci Technol. 2000;85: 89-98.

6. Waghorn GC, McNabb WC. Consequences of plant phenolic compounds for productivity and health of ruminants. Proc Nutr Soc. 2003;62:383-92.

7. AOAC. Official Methods of Analysis, 17th edn. Gaithersburg: Association of Official Analytical Chemists; 2000.

8. Van Soest PV, Robertson JB, Lewis BA. Methods for dietary fiber, neutral detergent fiber, and nonstarch polysaccharides in relation to animal nutrition. J Dairy Sci. 1991;74:3583-97.

9. Hagerman A, Harvey-Mueller I, Makkar HPS. Quantification of tannins in tree foliage-a laboratory manual. Vienna: FAO/IAEA; 2000. p. 4-7.

10. Makkar HPS. Quantification of tannins in tree and shrub foliage: a laboratory manual. Dordrecht: Kluer Academic Publishers; 2003.

11. Menke KH, Raab L, Salewski A, Steingass H, Fritz D, Schneider W. The estimation of the digestibility and metabolizable energy content of ruminant feeding stuffs from the gas production when they are incubated with rumen liquor in vitro. J Agri Sci. 1979;93:217-22.

12. Schofield P, Pitt RE, Pell AN. Kinetics of fibre digestion from in vitro gas production. J Anim Sci. 1994;72:2980-91.

13. Menke KH, Steingass H. Estimation of the energetic feed value obtained from chemical analysis and in vitro gas production using rumen fluid. Anim Re Dev. 1988;28:7-55.

14. ICAR. Nutrient Requirement of Sheep, Goat and Rabbit, second ed. New Delhi: Indian Council of Agricultural Research; 2013.

15. Sharma SC, Sahoo A. Promising Feed \& Fodder Resources for Dry Areas. Avikanagar: Central Sheep and Wool Research Institute; 2017.

16. Singh B, Sahoo A, Sharma R, Bhat TK. Effect of polethylene glycol on gas production parameters and nitrogen disappearance of some tree forages. Anim Feed Sci Technol. 2005:123:351-64.

17. Rana KK, Wadhwa M, Bakshi MPS. Seasonal variations in tannin profile of tree leaves. Asian-Australas J Anim Sci. 2006;19:1134-8.

18. Sahoo A, Ogra RK, Sood A, Ahuja PS. Nutritional evaluation of bamboo cultivars in sub_Himalayan region of India by chemical composition and in vitro ruminal fermentation. Grassl Sci. 2010;56:116-25.

19. Blummel M, Bullerdick P. The need to complement in vitro gas measurements with residue determination from in sacco degradabilities to improve the prediction of voluntary intake of hays. Anim Sci. 1997;64:71-5.

20. Blümmel M, Makkar HPS, Becker K. In vitro gas production: a technique revisited. J Anim Physiol Anim Nutr. 1997;77:24-34.

21. Nsahlai IV, Siaw D, Osuji PO. The relationships between gas production and chemical composition of 23 browses of the genus Sesbania. J Sci Food Agric. 1994;65:13-20.

22. Tavendale MH, Meagher $L P$, Pacheco D, Walker N, Attwood GT, Sivakumaran S. Methane production from in vitro rumen incubations with Lotus pedunculatus and Medicago sativa, and effects of extractable condensed tannin fractions on methanogenesis. Anim Feed Sci Technol. 2005;123:403-19.

23. Bhatta R, Saravanan M, Baruah L, Sampath KT. Nutrient content, in vitro ruminal fermentation characteristics and methane reduction potential of tropical tannin-containing leaves. J Sci Food Agric. 2012; 92:2929-35.

24. Archimede $H$, Eugene $M$, Marie Magdeleine $C$, Boval M, Martin C, Morgavi DP, Lecomte P, Doreau M. Comparison of methane production between C3 and C4 grasses and legumes. Anim Feed Sci Technol. 2011;166:59-64

25. Parmar P, Bhatt S, Dhyani S, Jain A. Phytochemical studies of the secondary metabolites of Ziziphus mauritania Lam. Leaves Int J Curr Pharm Res. 2012:4:153-5.

26. Goel G, Makkar HP. Methane mitigation from ruminants using tannins and saponins. Trop Anim Health Prod. 2012;44:729-39. 
27. Patra AK, Saxena J. A new perspective on the use of plant secondary metabolites to inhibit methanogenesis in the rumen. Phytochemistry. 2010; 71:1198-222.

28. Jayanegara A, Leiber F, Kreuzer M. Meta-analysis of the relationship between dietary tannin level and methane formation in ruminants from in vivo and in vitro experiments. J Anim Physiol Anim Nutr. 2012;96:365-75.

29. Beauchemin KA, Kreuzer M, Mara FO, McAllister TA. Nutritional management for enteric methane abatement: a review. Aust J Exp Agric. 2008;48:21-7.

Ready to submit your research? Choose BMC and benefit from:

- fast, convenient online submission

- thorough peer review by experienced researchers in your field

- rapid publication on acceptance

- support for research data, including large and complex data types

- gold Open Access which fosters wider collaboration and increased citations

- maximum visibility for your research: over $100 \mathrm{M}$ website views per year

At BMC, research is always in progress.

Learn more biomedcentral.com/submissions 